\title{
Juglanin ameliorates UVB-induced skin carcinogenesis via anti-inflammatory and proapoptotic effects in vivo and in vitro
}

\author{
GUI-RONG HOU, KANG ZENG, HAI-MEI LAN and QI WANG
}

Department of Dermatology, Nanfang Hospital, Nanfang Medical University, Guangzhou, Guangdong 510515, P.R. China

Received July 6, 2016; Accepted December 15, 2017

DOI: $10.3892 / \mathrm{ijmm} .2018 .3601$

\begin{abstract}
Ultraviolet (UV) radiation induces skin injury, and is associated with the development and formation of melanoma, which is a highly lethal form of skin cancer. Juglanin is a natural product, which is predominantly extracted from Polygonum aviculare, and is considered a functional component among its various compounds. Juglanin has been reported to exert marked protective effects in various diseases via the inhibition of inflammation and tumor cell growth. The present study aimed to explore the effects of juglanin on human skin cancer induced by UV and to reveal the underlying molecular mechanism. In the present study, immunohistochemical analysis, western blot analysis, RT-qPCR analysis and flow cytometry assays were mainly used in vivo and/or in vitro. The results indicated that in mice, UVB exposure increased susceptibility to carcinogens, and accelerated disease pathogenesis. Conversely, juglanin was able to ameliorate this condition via inhibition of inflammation, suppression of cell proliferation and induction of apoptosis via p38/c-Jun N-terminal kinase (JNK) blockage, nuclear factor $(\mathrm{NF})-\kappa \mathrm{B}$ inactivation and caspase stimulation in vivo. In addition, in vitro, the present study demonstrated that treatment of UVB-stimulated B16F10 melanoma cells with juglanin resulted in a dose-dependent decrease in cell viability, as well as increased apoptosis via the upregulation of caspase expression and poly (ADP-ribose) polymerase cleavage. In addition, juglanin markedly attenuated p38/JNK signaling, inactivated the phosphoinositide 3-kinase/protein kinase $\mathrm{B}$ pathway and suppressed UVB-induced NF- $\mathrm{B}$ activation. Taken together, these results indicated the possibility of applying juglanin in combination with UVB as a potential therapeutic strategy for preventing skin cancer.
\end{abstract}

Correspondence to: Dr Gui-Rong Hou, Department of Dermatology, Nanfang Hospital, Nanfang Medical University, 1838 North Guangzhou Avenue, Guangzhou, Guangdong 510515, P.R. China Email: houguirong510515@126.com

Key words: apoptosis, ultraviolet radiation, skin cancer, juglanin, inflammation

\section{Introduction}

Skin cancer, particularly non-melanoma skin cancers (NMSCs), including basal cell carcinoma and squamous cell carcinoma, is considered one of the most prevalent health concerns worldwide. Approximately 132,000 cases of melanoma and 2-3 million cases of NMSC are reported per annum globally $(1,2)$. Extensive exposure to sunlight has been closely associated with skin cancer (3), and the formation of skin cancer has been reported to be associated with one or numerous signaling pathways (4). Various coordinated biological alterations, including but not limited to epidermal hyperplasia, inflammation, oxidative stress and proliferation, are essential events associated with skin tumor progression $(4,5)$.

Juglanin is a natural compound extracted from crude Polygonum aviculare, which has been reported to exert inhibitory activity against the inflammatory response, as well as cancer growth (6-8). It has previously been suggested that juglanin inhibits apoptosis and the inflammatory response through Toll-like receptor 4-modulated mitogen-activated protein kinase (MAPK)/nuclear factor (NF)- $\mathrm{KB}$ and Janus kinase 2/signal transducer and activator of transcription 3 signaling pathways, respectively, in rats with hepatitis (9). In addition, juglanin has been revealed to decrease the levels of reactive oxygen species in senescent cells induced by adriamycin treatment (10). Furthermore, juglanin may exert inhibitory effects against lipopolysaccharide-induced cytokine production in RAW 264.7 macrophages, including interleukin (IL)-1 $\beta$, tumor necrosis factor (TNF)- $\alpha$ and IL-6 (11). However, to the best of our knowledge, the role of juglanin in autophagy and apoptosis in UVB-induced skin injury remains to be elucidated. Furthermore, it remains to be determined as to whether juglanin suppresses the growth of human skin cancer.

A previous study indicated that NF- $\mathrm{\kappa B}$ may serve an important role in the maintenance of skin homeostasis, as well as the regulation of various types of cell proliferation, resistance to apoptosis and survival (12). Various signaling pathways have been reported to have a crucial role in the response of cells to ultraviolet B (UVB) irradiation, including phosphoinositide 3-kinase (PI3K)/protein kinase B (AKT) signaling. In addition, the MAPK family subgroups, c-Jun N-terminal kinase (JNK) and $\mathrm{p} 38$, have been reported to serve an important role in cell apoptosis and proliferation $(13,14)$. UVB induces potentially lethal injuries to cellular DNA, thus initiating cellular recovery 
mechanisms, including activation of DNA damage response pathways and apoptosis (15). However, some DNA-injured cells could induce apoptosis, destruct differentiation control and even lead to the formation of cancerous cells in the end (16). Therefore, exploring novel therapeutic strategies for apoptotic induction, and the suppression of cell proliferation and inflammation in skin cancer is necessary.

The present study aimed to explore the effects of various doses of juglanin on UVB-induced mouse skin tumor formation and promotion in vivo. In vitro, B16F10 cells were used as a model of melanoma to determine the molecular mechanisms underlying the proapoptotic effects of juglanin on UVB-irradiated melanoma cells. The results demonstrated that juglanin promoted cell death of UVB-irradiated B16F10 cells, thus indicating that juglanin may be considered a potential compound to prevent against UVB-irradiated skin damage and skin cancer.

\section{Materials and methods}

Animals and treatment. A total of 40 SKH-1 hairless mice (age, 5-6 weeks; weight, 20 g) were initially obtained from Jackson Laboratory (Bar Harbor, ME, USA), and were maintained in our facility with free access to water and food, under a 12-h light/dark cycle, with $35 \%$ humidity. The mice were divided into four groups: The control (Con) group (without any UVB irradiation and juglanin treatment), the model (Mod) group (UVB irradiation), and the 10 and $20 \mathrm{mg} / \mathrm{kg}$ juglanin-treated groups, which were treated with juglanin after UVB irradiation. All experimental procedures were carried out in accordance with the Guide for the Care and Use of Laboratory Animals, and, before the animal experiments were carried out, the procedures were approved by the Research Ethical Committee of Southern Medical University (Guangdong, China).

The UV lamp (UVA-340; SolarSystems \& Solutions, LLC, Clifford, PA, USA) used to irradiate mice in the present study simulates sunlight in the critical short wavelength region, from $365 \mathrm{~nm}$ to the solar cut-off of $295 \mathrm{~nm}$, with a peak emission at $340 \mathrm{~nm}$. The radiant dose was quantified, at the appropriate distance, using a UVB Daavlin Flex Control Integrating Dosimeter (Daavlin, Bryan, OH, USA) and was further confirmed using an external radiometer (X-96 Irradiance Meter; Daavlin) before and after each irradiation session. An electrical fan was used to avoid excessive heating. As for the acute radiation experiments, mice were exposed to UV radiation at a dose of $600 \mathrm{~mJ} / \mathrm{cm}^{2}$ in groups and were euthanized 24 or $72 \mathrm{~h}$ after irradiation. For skin carcinogenesis experiments, the animals were exposed twice a week for 10 weeks on Mondays and Wednesdays to solar-simulated UV radiation in clear bedding-free cages. During the process, the animals were consecutively administered various doses (10 and $20 \mathrm{mg} / \mathrm{kg}$ ) of juglanin by gavage. Finally, the dorsal skin was harvested, and computer-assisted image analysis, using a Zeiss KS300 (version 3.0; München, Germany,) was used to observe vessel size. Some of the fresh skin tissue samples were immediately frozen in liquid $\mathrm{N}_{2}$ and stored at $-80^{\circ} \mathrm{C}$ for subsequent experiments.

Histopathological analysis. Fresh tissue samples were fixed in formalin for $48 \mathrm{~h}$ at room temperature. Then, the formalin-fixed, paraffin-embedded mouse skin samples were processed and were then stained with hematoxylin and eosin, based on a routine protocol (17). The stained tissue sections (5- $\mu \mathrm{m}$ thick) were then observed under a light microscope and digital micrographs of slides were captured for analysis.

Immunohistochemical analysis. For immunohistochemistry, fresh tissue samples were fixed in formalin for $48 \mathrm{~h}$ at room temperature. Subsequently, tissue samples were embedded in paraffin and cut into sections (5- $\mu$ m thick) using a microtome. The sections were then fixed onto slides. Endogenous peroxidase was blocked with $3 \% \mathrm{H}_{2} \mathrm{O}_{2}$, and non-specific proteins were blocked with $10 \%$ goat serum for $30 \mathrm{~min}$. The samples were then incubated with antibodies against KI67, TNF- $\alpha$ and proliferating cell nuclear antigen (PCNA) (1:100 dilution) in $5 \%$ horse serum (Life Technologies, Grand Island, NY, USA) with PBS at $4^{\circ} \mathrm{C}$ overnight. Sections were then incubated with diluted streptavidin-peroxidase horseradish peroxidase (1:200; cat. no. 6721; Abcam, Cambridge, MA, USA) for $30 \mathrm{~min}$ at room temperature using a Foxp3 staining kit (eBioscience, San Diego, CA, USA), according to the manufacturer's protocol. Finally, sections were stained with hematoxylin for $3 \mathrm{~min}$, and were mounted and assessed using a phase-contrast microscope (DP70; Olympus, Tokyo, Japan).

Cell culture and treatment. B16F10 murine melanoma cells and Hs68 human foreskin fibroblast cells were purchased from American Type Culture Collection (Manassas, VA, USA). The cells were maintained in a monolayer culture in Dulbecco's modified Eagle's medium (DMEM; Gibco, Grand Island, NY, USA) supplemented with $10 \%$ fetal bovine serum (FBS; Gibco), $0.012 \%$ penicillin $\mathrm{G}, 0.027 \%$ streptomycin, $0.022 \%$ sodium pyruvate and $0.26 \%$ sodium bicarbonate at $37^{\circ} \mathrm{C}$ in an atmosphere containing $95 \%$ air and $5 \% \mathrm{CO}_{2}$. Juglanin stock solution was prepared in dimethyl sulfoxide (DMSO) and was diluted to the desired final concentration $(10$ and $20 \mu \mathrm{M})$ in culture medium $24 \mathrm{~h}$ prior to use. The final concentration of DMSO did not exceed $0.1 \%(\mathrm{v} / \mathrm{v})$.

Cell viability analysis. The antiproliferative role of juglanin in B16F10 and human Hs68 cells was determined using the MTS Cell Proliferation Colorimetric Assay kit (Biovision, Inc., Milpitas, CA, USA). Briefly, cells were plated in 96-well plates at a density of $5 \times 10^{3}$ cells/well. After $12 \mathrm{~h}$, the cells were treated with various concentrations of juglanin (0-30 $\mu \mathrm{M})$ and/ or UVB $\left(5 \mathrm{~mJ} / \mathrm{cm}^{2}\right)$ for $24 \mathrm{~h}$. Subsequently, fresh MTS and PMS mixture was added and incubated for $2-4 \mathrm{~h}$ at $37^{\circ} \mathrm{C}$ according to the manufacturer's protocol. A MR7000 microplate reader (Dynatech Laboratories Inc., Chantilly, VA, USA) was used to determine the absorbance at $500 \mathrm{~nm}$. In addition, half maximal inhibitory concentration values were determined. Data are presented as the mean of five replicates; each experiment was conducted in triplicate.

Flow cytometric analysis. Cancer cell apoptosis was calculated via flow cytometry. Cells were harvested and washed three times with PBS, after which they were stained with Annexin V-fluorescein isothiocyanate (FITC) and propidium iodide (PI) in binding buffer. Apoptosis was assessed using a FACSCalibur flow cytometer (BD Biosciences, Franklin Lakes, 
NJ, USA) after 15 min incubation at room temperature in the dark. Fluorescence was detected at an excitation wavelength of $480 \mathrm{~nm}$ via FL-1 $(530 \mathrm{~nm})$ and FL-2 filters $(585 \mathrm{~nm})$. The number of apoptotic cells was then analyzed using Win-MDI software (version 2.9; http://facs.scripps.edu/wm29w98.exe).

Fluorescence imaging. Tissue samples were washed twice with PBS and fixed with $3.7 \%$ (v/v) formaldehyde in PBS for $15 \mathrm{~min}$. Cells were permeabilized for 5 min with $0.1 \%$ Triton X-100. For immunofluorescence, phosphorylated (p)-NF- $\kappa \mathrm{B}$ and $50 \mu \mathrm{g} / \mathrm{ml}$ mouse anti-caspase-3 antibodies were employed, followed by incubation with $2 \mu \mathrm{g} / \mathrm{ml}$ Alexa Fluor 488-goat anti-mouse secondary antibodies. DAPI (Sigma-Aldrich; Merck KGaA, Darmstadt, Germany) was also used to stain cells. Images were acquired by confocal laser scanning using epifluorescence microscopy (Nikon TE2000-E; Shanghai Sunny Biotech Co., Ltd., Shanghai, China).

Reverse transcription-quantitative polymerase chain reaction (RT-qPCR). Total RNA was extracted from tissue samples using the mirVana miRNA Isolation kit (Ambion; Thermo Fisher Scientific, Inc. , Waltham, MA, USA) according to the manufacturer's protocol. Subsequently, cDNA was synthesized from total RNA using the TaqMan miRNA RT kit (Applied Biosystems; Thermo Fisher Scientific, Inc.) according to the manufacturer's protocol. qPCR was conducted using the Applied Biosystems 7500 Sequence Detection system with $\mathrm{iQ}^{\mathrm{TM}}$ SYBR-Green Supermix (Bio-Rad Laboratories, Inc., Hercules, CA, USA) containing $5 \mathrm{ng}$ cDNA and $10 \mathrm{pM}$ each primer. Amplification of pre-denaturated products was conducted at $94^{\circ} \mathrm{C}$ for $60 \mathrm{sec}$; followed by 45 cycles at $95^{\circ} \mathrm{C}$ for $30 \mathrm{sec}, 58^{\circ} \mathrm{C}$ for $30 \mathrm{sec}$ and $72^{\circ} \mathrm{C}$ for $30 \mathrm{sec}$; followed by $95^{\circ} \mathrm{C}$ for $10 \mathrm{sec}, 65^{\circ} \mathrm{C}$ for $45 \mathrm{sec}$, and $40^{\circ} \mathrm{C}$ for $60 \mathrm{sec}$. Data were normalized to the geometric mean of the housekeeping gene GAPDH, and relative mRNA expression levels were calculated using the $2^{-\Delta \Delta \mathrm{Cq}}$ method (18). Fold changes in the mRNA levels of target genes relative to the endogenous GAPDH control were calculated. Briefly, the quantification cycle $(\mathrm{Cq})$ values of each target gene were subtracted from the $\mathrm{Cq}$ values of the housekeeping gene GAPDH $(\Delta \mathrm{Cq})$. The target gene $\Delta \Delta \mathrm{Cq}$ was calculated as $\Delta \mathrm{Cq}$ of target gene - $\Delta \mathrm{Cq}$ of control gene. The fold change in mRNA expression was evaluated as $2^{-\Delta \Delta C q}$. The primer sequences used in the present study were as follows: IL-1 $\beta$, sense (5'-3') GTG AGG AGA AGA TGG GTA G, antisense (5'-3') AGA CCT AGG GAA GAA CCA AT; IL-18, sense (5'-3') AGG TAA CCT ACA AGA CGT GG, antisense (5'-3') TTA CCA GAT CGG TGA GAG AT; and GAPDH, sense (5'-3') ATC AAC ACG AGG CTA GCA GG and antisense (5'-3') CAT CAT ACA CGC ACC ACA GTC AC.

Western blotting. Melanoma cells were homogenized in $10 \%$ (wt/vol) hypotonic buffer $[25 \mathrm{mM}$ Tris- $\mathrm{HCl}(\mathrm{pH} 8.0)$, $1 \mathrm{mM}$ EDTA, $5 \mu \mathrm{g} / \mathrm{ml}$ leupeptin, $1 \mathrm{mM}$ Pefabloc SC, $50 \mu \mathrm{g} / \mathrm{ml}$ aprotinin, $5 \mu \mathrm{g} / \mathrm{ml}$ soybean trypsin inhibitor and $4 \mathrm{mM}$ benzamidine] to yield a homogenate. The final supernatants were obtained by centrifugation at $10,800 \times \mathrm{g}$ for $20 \mathrm{~min}$ at $4^{\circ} \mathrm{C}$. Protein concentration was determined using the bicinchoninic acid protein assay kit (Thermo Fisher Scientific, Inc.) with bovine serum albumin as a standard. Total protein extracts were used for western blotting. Equal amounts of total protein
(40 $\mu \mathrm{g}$ ) were loaded and proteins were separated using $10 \%$ SDS-PAGE and electrophoretically transferred to the polyvinylidene difluoride membranes (Millipore, Billerica, MA, USA). The membranes were then blocked with $5 \%$ skim milk Tris buffered saline with $0.1 \%$ Tween 20 (TBST), washed, and then incubated with primary antibodies overnight at $4{ }^{\circ} \mathrm{C}$. The membrane was then washed with TBST for three times, followed by incubation with a horseradish peroxidase (HRP)conjugated secondary antibody (1:2,500; cat. no. 6721; Abcam) at room temperature for $2 \mathrm{~h}$. Following another round of washing with TBST, the membrane was then developed using ECL (Thermo Fisher Scientific, Inc.), and exposed to Kodak X-ray film (Kodak, Rochester, NY, USA). Protein expression levels were defined as grey value using ImageJ (version 1.4.2b, Mac OS X; National Institutes of Health, Bethesda, MD, USA) and standardized to the housekeeping gene (GAPDH) and expressed as a fold of control. All experiments were performed in triplicate and done three times independently. The primary polyclonal antibodies used were as follows: rabbit anti-GAPDH (1:500; cat. no. sc-293335; Santa Cruz Biotechnology, Inc., Dallas, TX, USA), p38 (1:1,000; cat. no. 8690; Cell Signaling Technology, Inc., Danvers, MA, USA), p-p38 (1:1,000; cat. no. 4511, Cell Signaling Technology, Inc.), p-JNK (1:1,000; cat. no. 4668, Cell Signaling Technology, Inc.), JNK (1:1,000; cat. no. 9252, Cell Signaling Technology, Inc.), TNF- $\alpha$ (1:1,000; cat. no. ab1793; Abcam), IL-18 (1:1,000; cat. no. ab71495; Abcam), IL-1 $\beta$ (1:1,000; cat. no. ab9722; Abcam), p-NF-кB (1:1,000; cat. no. ab86299; Abcam), NF-кB (1:1,000; cat. no. ab207297; Abcam), PI3K (1:1,000; cat. no. ab86714; Abcam), p-AKT (1:1,000; cat. no. 81283; Abcam), AKT (1:1,000; cat. no. ab8805; Abcam), p-mammalian target of rapamycin (mTOR; 1:1,000; cat. no. ab109268; Abcam), mTOR (1:1,000; cat. no. ab2732; Abcam), poly (ADP-ribose) polymerase (PARP; 1:1,000; cat. no. ab13907; Abcam), cyclin-dependent kinase (CDK1; 1:1,000; cat. no. ab18; Abcam), cyclin D (1:1,000; cat. no. ab134175; Abcam), p53 (1:1,000; cat. no. ab26; Abcam), p21 (1:1,000; cat. no. ab109199; Abcam), p27 (1:1,000; cat. no. ab62364; Abcam), caspase-8 (1:1,000; cat. no. ab25901; Abcam), caspase-3 (1:1,000; cat. no. ab52293; Abcam) and PCNA (1:1,000; cat. no. ab29; Abcam).

Statistical analysis. Data are presented as the means \pm standard deviation (SD). Experimental groups were compared using GraphPad PRISM (version 6.0; GraphPad Software, Inc., La Jolla, CA, USA) by one-way analysis of variance with Dunn's least significant difference tests. $\mathrm{P}<0.05$ was considered to indicate a statistically significant difference.

\section{Results}

Juglanin ameliorates $U V B$-induced skin carcinogenesis. UVB exposure has been known to stimulate hyperplasia or infiltration of inflammatory cells into animal skin (19). Therefore, the present study explored the role of juglanin in UVB-induced skin carcinogenesis. Notably, $72 \mathrm{~h}$ after exposure to solar-simulated UV radiation, when erythema development was most obvious, the skin of the juglanin-treated mice exhibited no apparent erythema compared with the mice in the Mod group (Fig. 1A). Having established the effects of juglanin on UVB-induced skin injury, the present study explored the effects of $600 \mathrm{~mJ} / \mathrm{cm}^{2}$ 

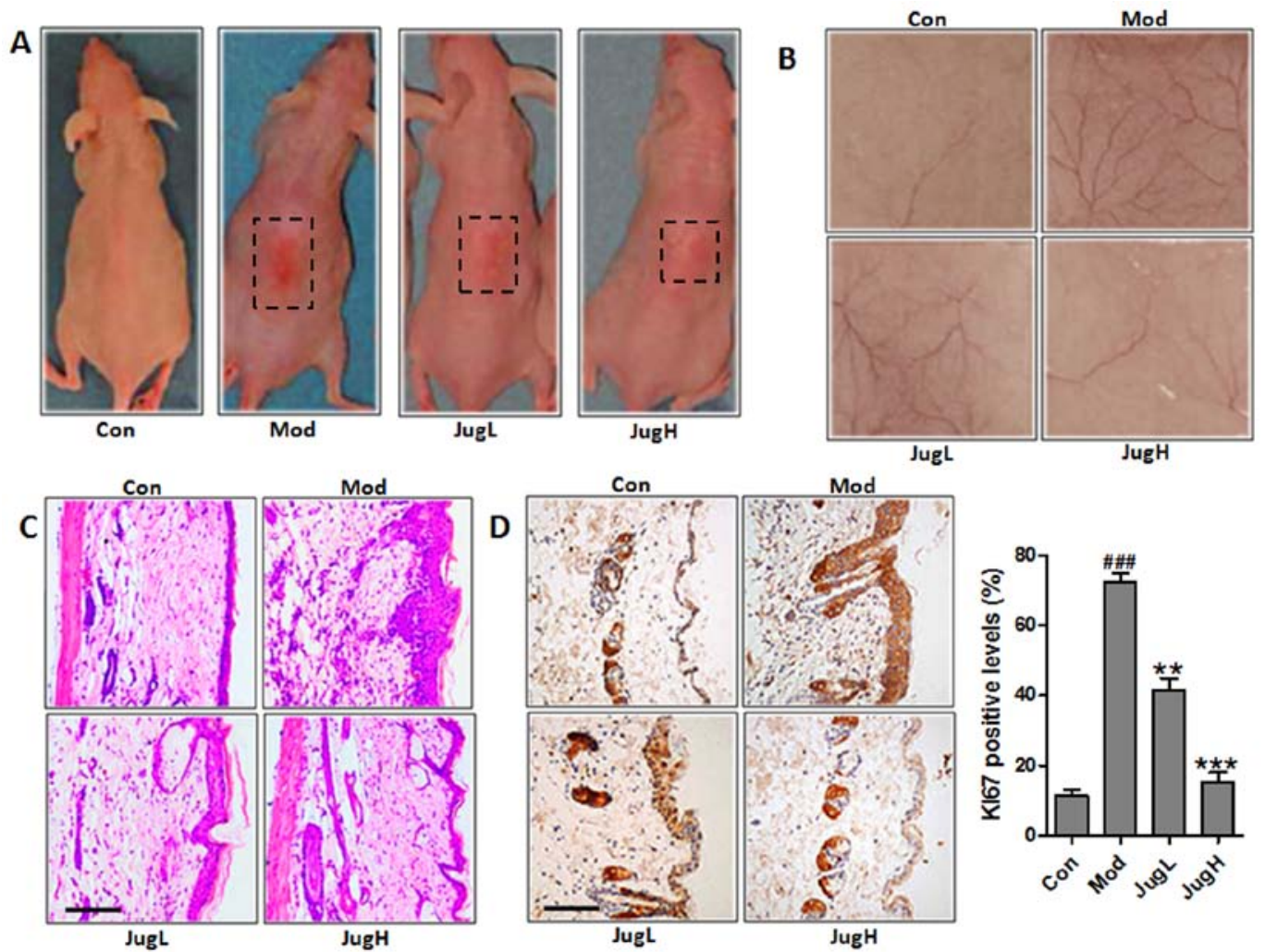

Figure 1. Juglanin ameliorates UVB-induced skin carcinogenesis. (A) Photographs of Con, Mod and juglanin-treated hairless mice exhibiting erythema following irradiation. (B) Representative images of dorsal skin vasculature of 6 individual animals from each group. (C) Hematoxylin and eosin staining. The representative photomicrographs from each group were shown (scale bar, $100 \mu \mathrm{m}$ ). (D) Immunohistochemical analysis of KI-67 was conducted on 5- $\mu \mathrm{m}$ sections. Representative photomicrographs from each group were shown (scale bar, $100 \mu \mathrm{m}$ ). Data are presented as the means \pm standard deviation of three independent experiments.

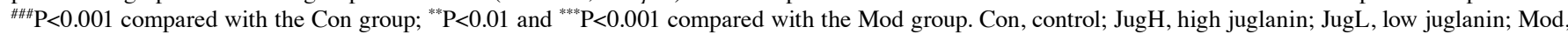
model; UVB, ultraviolet B.

A

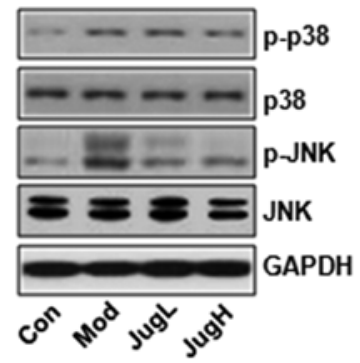

B

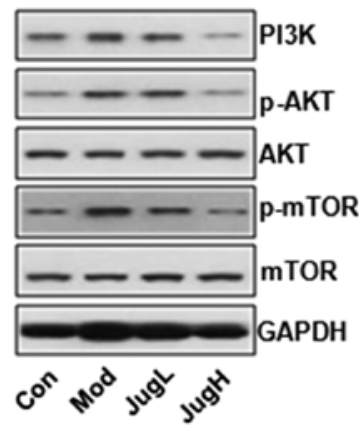

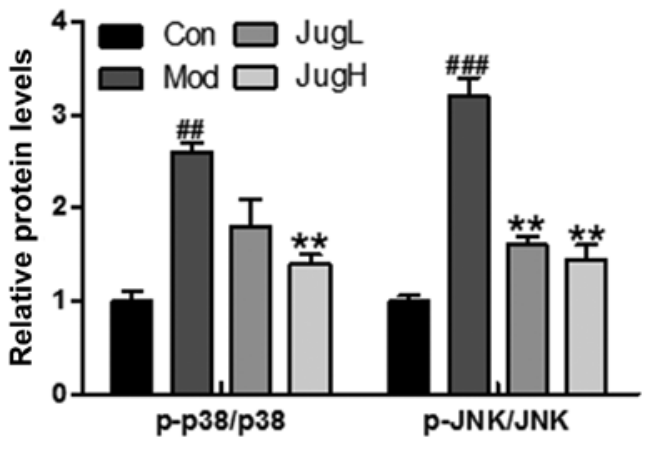

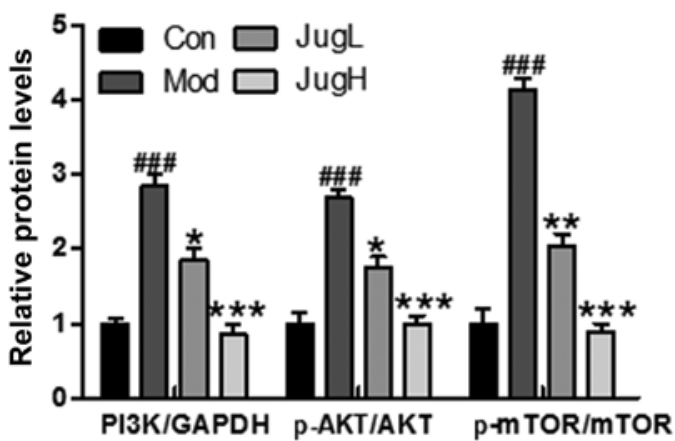

Figure 2. Effects of juglanin on UVB-induced p38/JNK and PI3K/AKT signaling activity. Western blotting was conducted and relative protein expression levels of (A) p-p38 and p-JNK, and (B) PI3K, p-AKT and p-mTOR were determined. Data are presented as the means \pm standard deviation of three independent experiments. ${ }^{\# \#} \mathrm{P}<0.01$ and ${ }^{\# \# \#} \mathrm{P}<0.001$ compared with the Con group; ${ }^{*} \mathrm{P}<0.05,{ }^{* *} \mathrm{P}<0.01$ and ${ }^{* * *} \mathrm{P}<0.001$ compared with the Mod group. AKT, protein kinase $\mathrm{B}$; Con, control; JNK, c-Jun N-terminal kinase; JugH, high juglanin; JugL, low juglanin; Mod, model; mTOR, mammalian target of rapamycin; p-, phosphorylated; PI3K, phosphoinositide 3-kinase; UVB, ultraviolet B. 
A

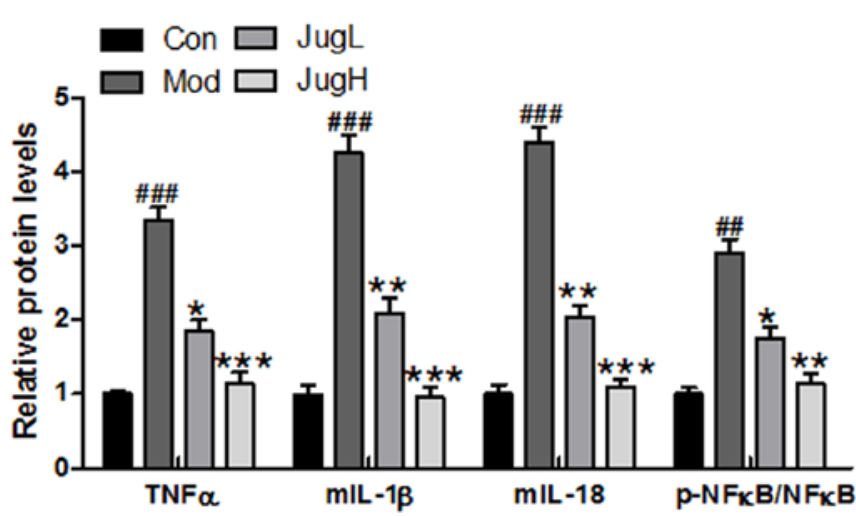

B

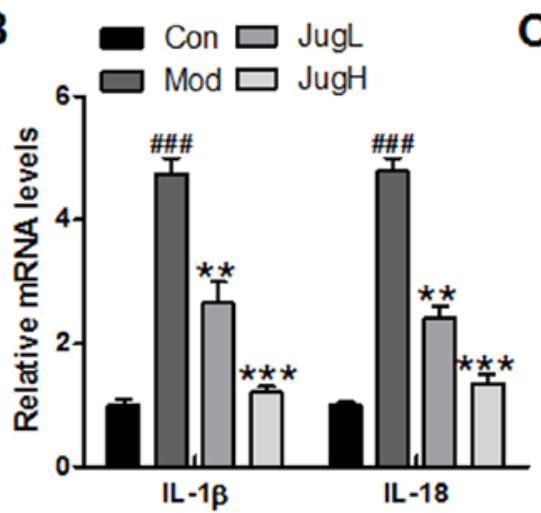

C
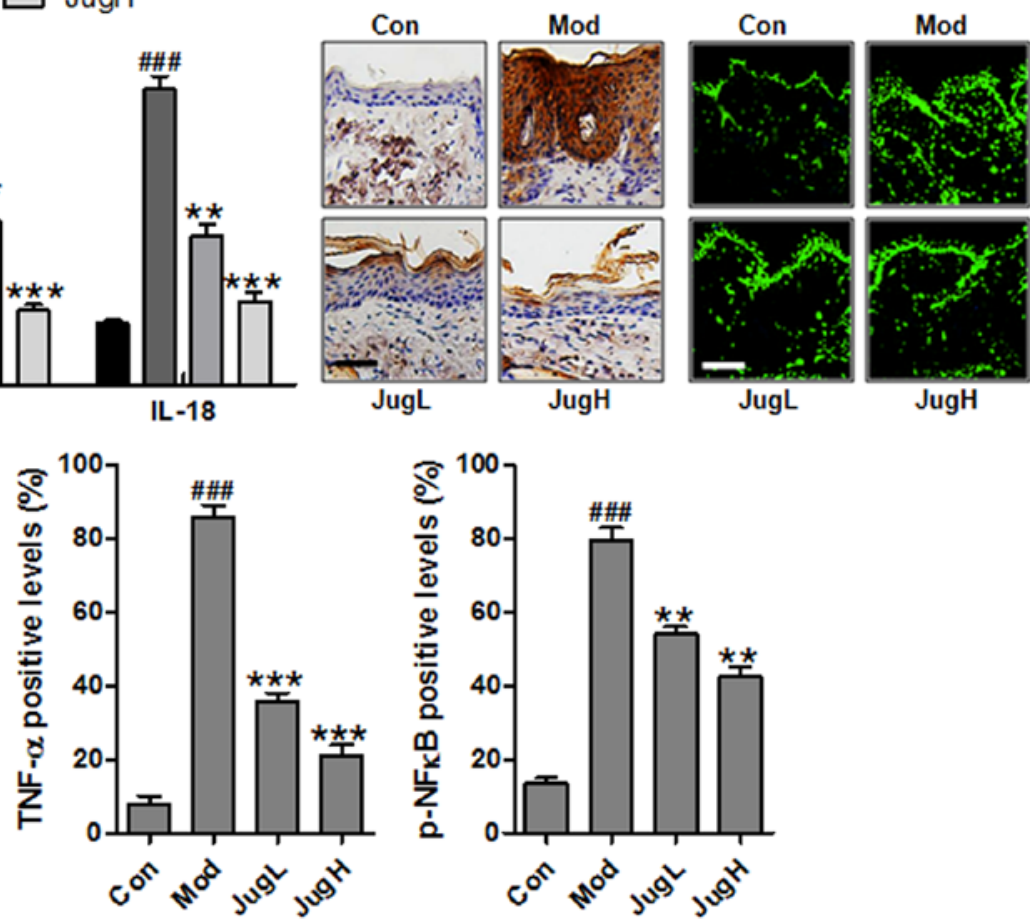

Figure 3. Effects of juglanin on UVB-induced inflammation. (A) Western blotting was conducted and relative expression levels of the following inflammation-associated proteins, TNF- $\alpha$, IL-1 $\beta$, IL-18 and p-NF- $\mathrm{kB}$, were determined. (B) Reverse transcription-quantitative polymerase chain reaction analysis was performed to determine the mRNA expression levels of inflammation-associated genes, IL-1 $\beta$ and IL-18. (C) Immunohistochemical analysis of TNF- $\alpha$ was conducted on 5- $\mu \mathrm{m}$ sections. Representative photomicrographs from each group were shown (scale bar, $100 \mu \mathrm{m}$ ). (D) Immunofluorescence analysis of p-NF- $\mathrm{kB}$ was conducted on tissue sections. Representative photomicrographs from each group were shown (scale bar, $100 \mu \mathrm{m}$ ). Data are presented as the means \pm standard deviation of three independent experiments. ${ }^{\# \# *} \mathrm{P}<0.001$ compared with the Con group; ${ }^{* *} \mathrm{P}<0.01$ and ${ }^{* * *} \mathrm{P}<0.001$ compared with the Mod

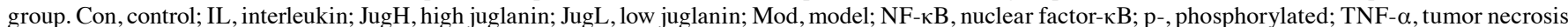
factor- $\alpha$; UVB, ultraviolet B.

solar-simulated UV radiation on normal mice; juglanin exerted dose-dependent alterations in the appearance of skin vasculature $24 \mathrm{~h}$ after exposure (Fig. 1B). UVB exposure led to upregulated epidermal thickness in the Mod group, as well as the infiltration of inflammatory cells compared with in the control mice (Fig. 1C). Following UVB exposure, administration of juglanin (10 and $20 \mathrm{mg} / \mathrm{kg}$ to mice) led to the suppression of epidermal hyperplasia and inflammatory cell infiltration compared with in the Mod group (Fig. 1C). KI67 expression was assessed in the skin of UVB-induced mice administered juglanin. In mice in the Mod group, the expression levels of KI67 were markedly higher compared with in the control mice. However, juglanin treatment significantly downregulated KI67 expression in the skin of UVB-exposed mice compared with in the Mod group (Fig. 1D). Taken together, these results suggested that juglanin exerts potential effects on the amelioration of UVB-stimulated skin carcinogenesis in animals.

Juglanin suppresses UVB-induced p38/JNK and PI3K/AKT activity. Phosphorylation of p38 and JNK is an indicator of cellular stress following exposure to UV radiation (20). Therefore, the phosphorylated levels of $\mathrm{p} 38$ and JNK were investigated in the present study. The results suggested that $\mathrm{p} 38$ and JNK phosphorylation levels were increased in mice following UV exposure compared with in the control group (Fig. 2A). However, juglanin treatment significantly reduced the increased expression of p-p38 and p-JNK compared with in the Mod group (Fig. 2A). In addition, the PI3K/AKT signaling pathway 
A
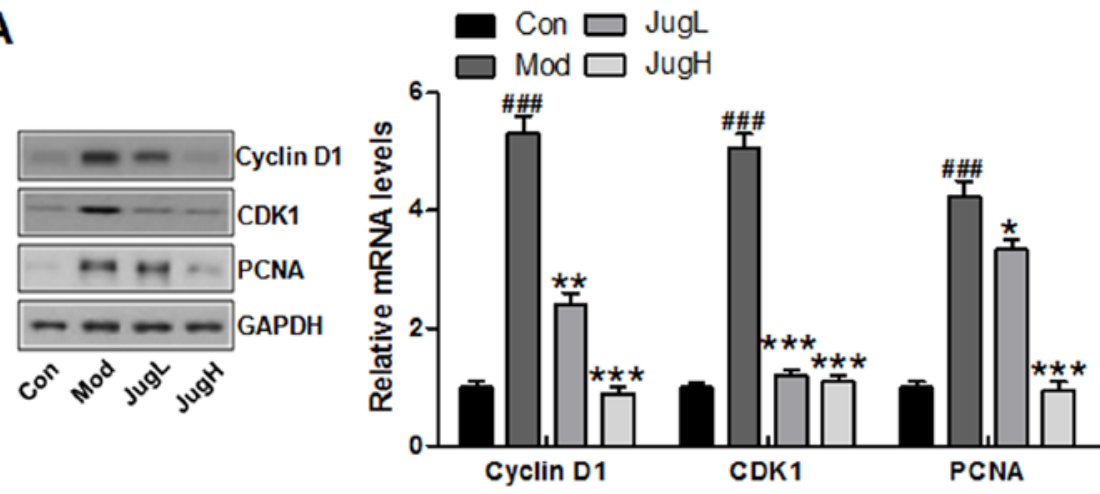

B

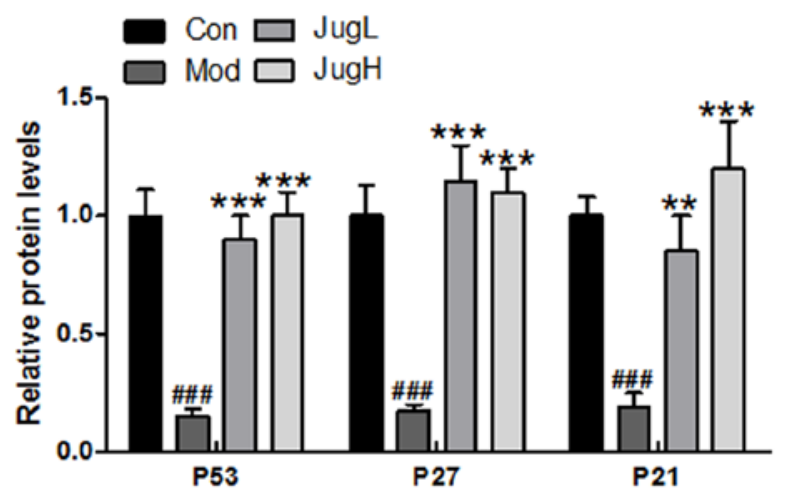

C
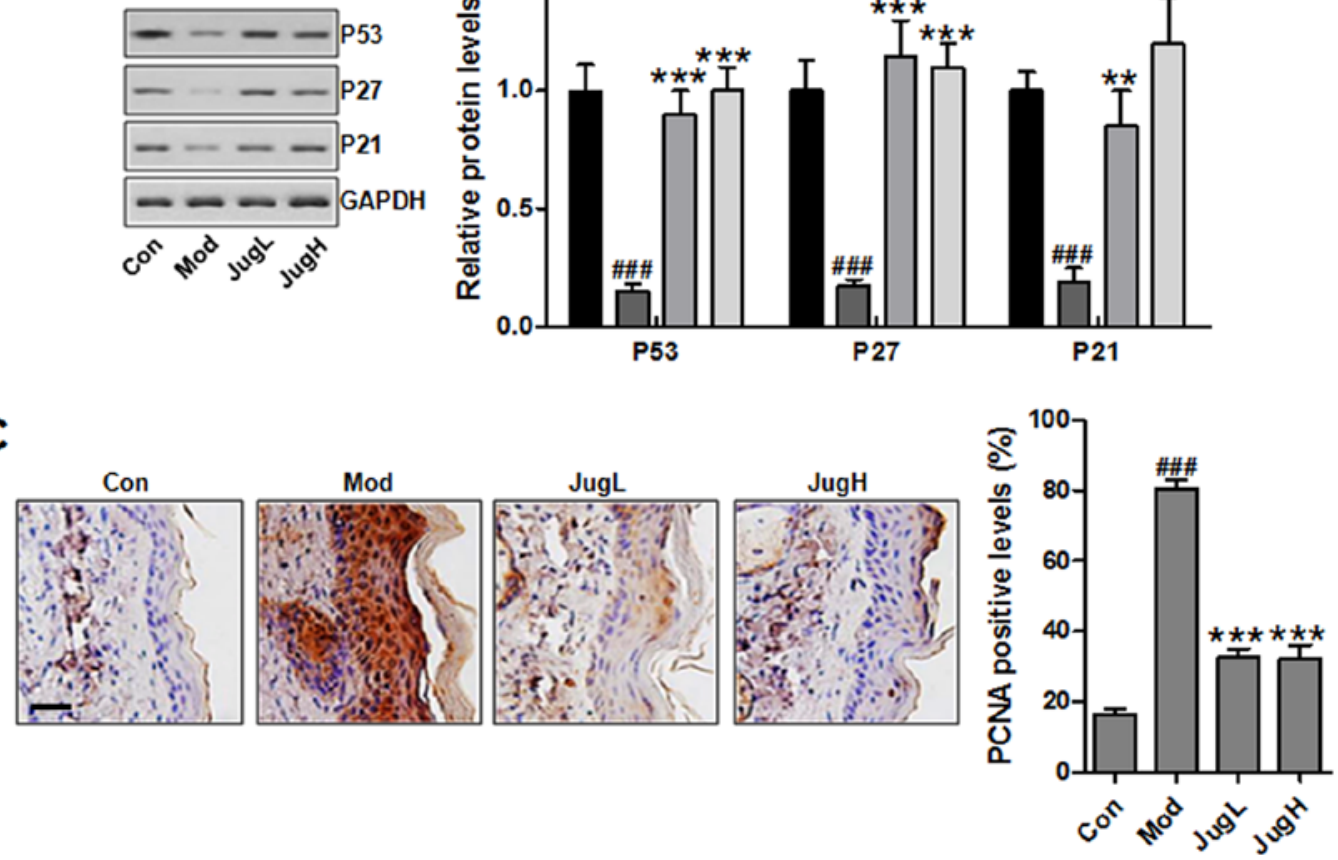

Figure 4. Effects of juglanin on UVB-induced cell proliferation markers. (A) Western blotting was conducted and relative protein expression levels of cyclin D1, CDK1 and PCNA were determined. Equal protein loading was confirmed by stripping the immunoblot and reprobing it for GAPDH. (B) Western blotting was conducted and relative protein expression levels of p53, p27 and p21 were determined. (C) Immunohistochemical analysis of PCNA was conducted on 5- $\mu \mathrm{m}$ sections. Representative photomicrographs from each group were shown (scale bar, $100 \mu \mathrm{m}$ ). Data are presented as the means \pm standard deviation of three independent experiments. ${ }^{\# \# \#} \mathrm{P}<0.001$ compared with the Con group; ${ }^{* *} \mathrm{P}<0.01$ and ${ }^{* * *} \mathrm{P}<0.001$ compared with the Mod group. CDK1, cyclin-dependent kinase 1; Con, control; JugH, high juglanin; JugL, low juglanin; Mod, model; PCNA, proliferating cell nuclear antigen; UVB, ultraviolet B.

has been reported to be involved in UV exposure-induced skin cancer (21). In the present study, PI3K was activated in the Mod group, whereas juglanin reduced PI3K expression. In addition, UV-induced p-AKT expression was downregulated by juglanin in a dose-dependent manner (Fig. 2B). mTOR is regulated by the PI3K/AKT signaling pathway, and is closely associated with cancer progression (22). Finally, the present study demonstrated that upregulated mTOR phosphorylation was induced by UV, and was downregulated in the juglanin-treated groups (Fig. 2B). These findings indicated that $\mathrm{p} 38 / \mathrm{JNK}$ and $\mathrm{PI} 3 \mathrm{~K} / \mathrm{AKT}$ may be involved in the inhibitory effects of juglanin on skin cancer.

Juglanin inhibits UVB-induced inflammation. Skin inflammation has been reported to serve a role in UVB exposure-induced cancer progression, as determined by the enhancement of proin- flammatory cytokines, including IL-1 $\beta$, TNF- $\alpha$ and IL-18 (23). IL-1 $\beta$ is associated with the hemostatic function of normal skin in animals, but is also involved in various pathophysiological situations, including inflammation, when generated excessively. IL-1 $\beta$ can be secreted from infiltrated macrophages, mast cells and keratinocytes following exposure to UV (24). TNF- $\alpha$ enhances the local inflammatory response in the epidermis and possesses an essential role in photodamage (25). Furthermore, IL-6 has an essential role in the acute phase response during acute inflammation, and production of IL- 6 is increased in the skin following UV exposure (26). The expression levels of proinflammatory cytokines were detected in the skin from UVB-exposed mice treated with juglanin. In UVB-exposed mice, the protein expression levels of TNF- $\alpha$, IL-1 $\beta$ and IL- 6 were significantly upregulated compared with in the control group. Conversely, treatment with juglanin significantly 

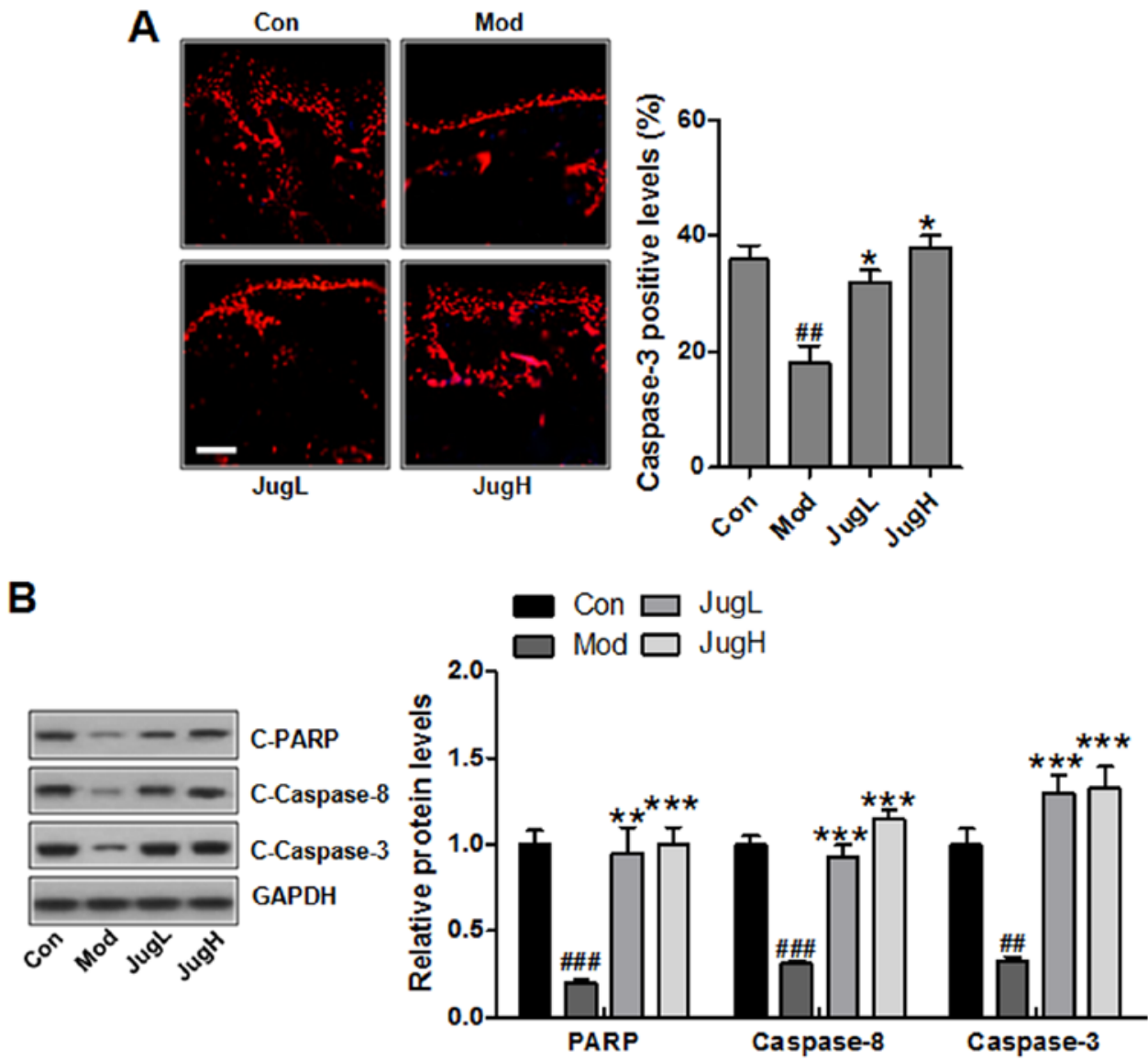

Figure 5. Juglanin induces caspase activation and PARP-1 cleavage. (A) Immunofluorescence analysis of caspase-3 was conducted on tissue sections. Representative photomicrographs from each group were shown (scale bar, $100 \mu \mathrm{m}$ ). (B) Western blotting was conducted and relative protein expression levels of C-caspase-3, C-caspase-8 and C-PARP were determined. Equal protein loading was confirmed by stripping the immunoblot and reprobing it for GAPDH. Data are presented as the means \pm standard deviation of three independent experiments. ${ }^{\# \#} \mathrm{P}<0.01$ and ${ }^{\# \# \#} \mathrm{P}<0.001$ compared with the Con group; ${ }^{*} \mathrm{P}<0.05$, ${ }^{* *} \mathrm{P}<0.01$ and ${ }^{* * *} \mathrm{P}<0.001$ compared with the Mod group. C-, cleaved; Con, control; JugH, high juglanin; JugL, low juglanin; Mod, model; PARP, poly (ADP-ribose) polymerase; UVB, ultraviolet B.

reduced the protein expression levels of IL-1 $\beta$, TNF- $\alpha$ and IL-6 in the skin of UVB-exposed mice compared with in the Mod group (Fig. 3A). NF- $\kappa \mathrm{B}$ is an essential regulator that contributes to the release of proinflammatory cytokines (27). The present study demonstrated that $\mathrm{NF}-\kappa \mathrm{B}$ was activated in mice exposed to UV, which was downregulated by juglanin administration (Fig. 3A). As shown in Fig. 3B, RT-qPCR was used to confirm that UV-induced activation of IL-1 $\beta$ and IL-6 was downregulated by juglanin administration (Fig. 3B). In addition, TNF- $\alpha$ was stimulated in the Mod group, whereas juglanin treatment could reverse this UV-induced overexpression, as determined by immunohistochemical analysis (Fig. 3C). Finally, immunofluorescence analysis indicated that NF- $\kappa \mathrm{B}$ was activated in the Mod group, whereas juglanin administration was able to reduce $\mathrm{p}-\mathrm{NF}-\kappa \mathrm{B}$ activation (Fig. 3D). Taken together, these data indicated that juglanin may ameliorate skin carcinogenesis via the suppression of inflammation.

Role of juglanin in UVB-induced cell proliferation. UVB induces cell proliferation by initiating cell cycle-associated signaling pathway activation. Therefore, the present study explored the role of juglanin in the proliferative potential of epidermal cells following exposure to UVB. As shown in Fig. 4A, exposure of mice to UVB led to upregulated expression of cyclin D1, CDK1 and PCNA compared with in the control group. Conversely, juglanin treatment decreased the expression levels of these proteins. UVB-induced skin damage is associated with the ability of cells to assess or reverse DNA damage, regulating the cell cycle and inducing apoptosis if necessary. In UVB-exposed skin, DNA damage leads to p53 expression, as well as its downstream target proteins p27 and p21 (28). As presented in Fig. 4B, UVB exposure downregulated p53, p27 and p21 protein expression compared with in the control group. In addition, juglanin administration to UVB-induced mice promoted p53, p27 and p21 expression. Immunohistochemical analysis indicated that PCNA was upregulated in UV-induced mice, whereas juglanin administration was able to reduce PCNA expression; this finding was in accordance with the results of western blotting (Fig. 4C).

Juglanin induces caspase activation and PARP-1 cleavage. As aforementioned, apoptosis may be associated with UV-induced skin cancer progression. In the present study, the results of an immunofluorescence assay suggested that caspase-3 was suppressed following UV induction in mice (Fig. 5A). Notably, juglanin significantly enhanced caspase-3 levels; caspase-3 is an essential regulator that leads to apoptosis (29). 

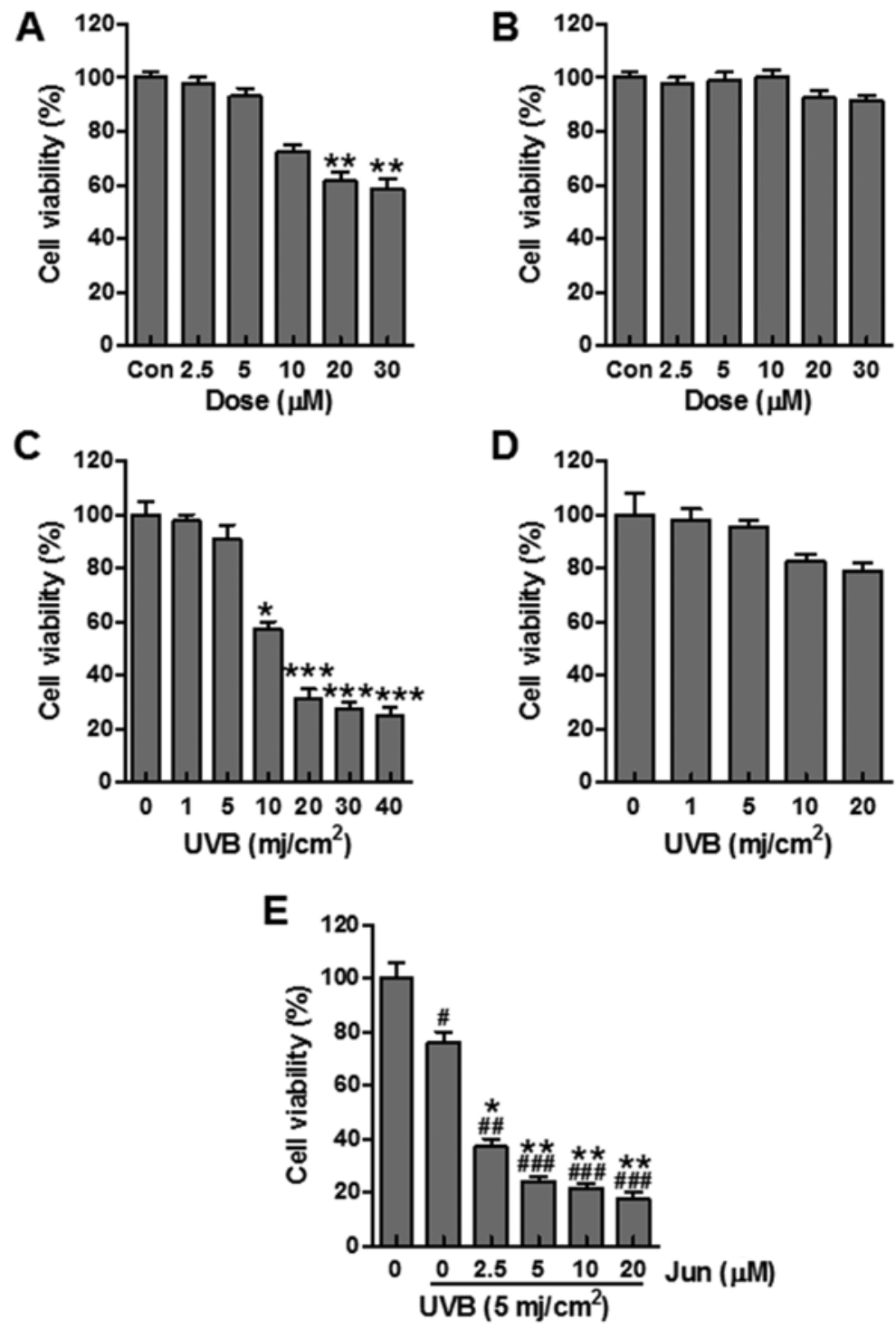

Figure 6. Jun promotes UVB-induced cell death. (A) Analysis of the viability of (A) B16F10 and (B) Hs68 Jun-treated cells, as determined using the MTS assay. Analysis of the viability of (C) B16F10 and (D) Hs68 cells $24 \mathrm{~h}$ post-UVB irradiation, as determined using the MTS assay. ${ }^{*} \mathrm{P}<0.05,{ }^{* *} \mathrm{P}<0.01$ and ${ }^{* * * *} \mathrm{P}<0.01$ compared with the Con group. (E) Analysis of the viability of B16F10 cells treated with Jun and/or UVB $\left(5 \mathrm{~mJ} / \mathrm{cm}^{2}\right)$ for $24 \mathrm{~h}$, as determined using the MTS assay. ${ }^{\#} \mathrm{P}<0.05,{ }^{\# \#} \mathrm{P}<0.01$ and ${ }^{\# \# \#} \mathrm{P}<0.001$ compared with the Con group; ${ }^{*} \mathrm{P}<0.05$ and ${ }^{* *} \mathrm{P}<0.01$ compared with the UVB group. Data are presented as the means \pm standard deviation of three independent experiments. ${ }^{\# \# \#} \mathrm{P}<0.001$ compared with the Con group; ${ }^{* * *} \mathrm{P}<0.01$ and ${ }^{* * * *} \mathrm{P}<0.001$ compared with the Mod group. Jun, juglanin; UVB, ultraviolet B.

Furthermore, western blotting indicated that PARP, caspase- 8 and -3 cleavage was enhanced in UV-exposed mice treated with juglanin (Fig. 5B).

Juglanin promotes UVB-induced cell death.In order to further examine the effects of juglanin on skin cancer, B16F10 cells were exposed to UVB $\left(1-40 \mathrm{~mJ} / \mathrm{cm}^{2}\right)$ and the cell viability was determined at $24 \mathrm{~h}$ post-UVB irradiation. In addition, B16F10 cells were administered juglanin $(2.5-30 \mu \mathrm{M})$ and cell viability was investigated. Juglanin $(2.5-10 \mu \mathrm{M})$ did not induce $\mathrm{B} 16 \mathrm{~F} 10$ cell death, whereas 20 and $30 \mu \mathrm{M}$ juglanin significantly reduced cell viability (Fig. 6A). To determine the specificity of the proapoptotic effects of juglanin, Hs68 fibroblast cells were treated with juglanin and cell viability was analyzed. Notably, juglanin induced no significant cell death in Hs68 cells (Fig. 6B). In addition, the present study indicated that UVB exposure led to a significant downregula- tion in the viability of B16F10 cells (Fig. 6C). Upon UVB irradiation at $10 \mathrm{~mJ} / \mathrm{cm}^{2}$, the viability of B16F10 cells was decreased by $\sim 40 \%$ compared with in unirradiated control cells. However, $10 \mathrm{~mJ} / \mathrm{cm}^{2}$ UVB induced no apparent cell death of normal Hs68 human fibroblast cells, and was therefore selected for further experiments (Fig. 6D). The present study investigated whether juglanin enhanced cell death of UVB-irradiated B16F10 cells. The results indicated that treatment of UVB-irradiated $\mathrm{B} 16 \mathrm{~F} 10$ cells with 2.5 , 5,10 and $20 \mu \mathrm{M}$ juglanin increased the percentage of cell death (Fig. 6E). These results indicated that the effectiveness of juglanin to induce cell death was, at least partly, contributed to specific cell type and may rely on the concentration of administration.

$U V B$ and juglanin cotreatment enhances apoptotic cell death and induces caspase activation and PARP-1 cleavage. To 

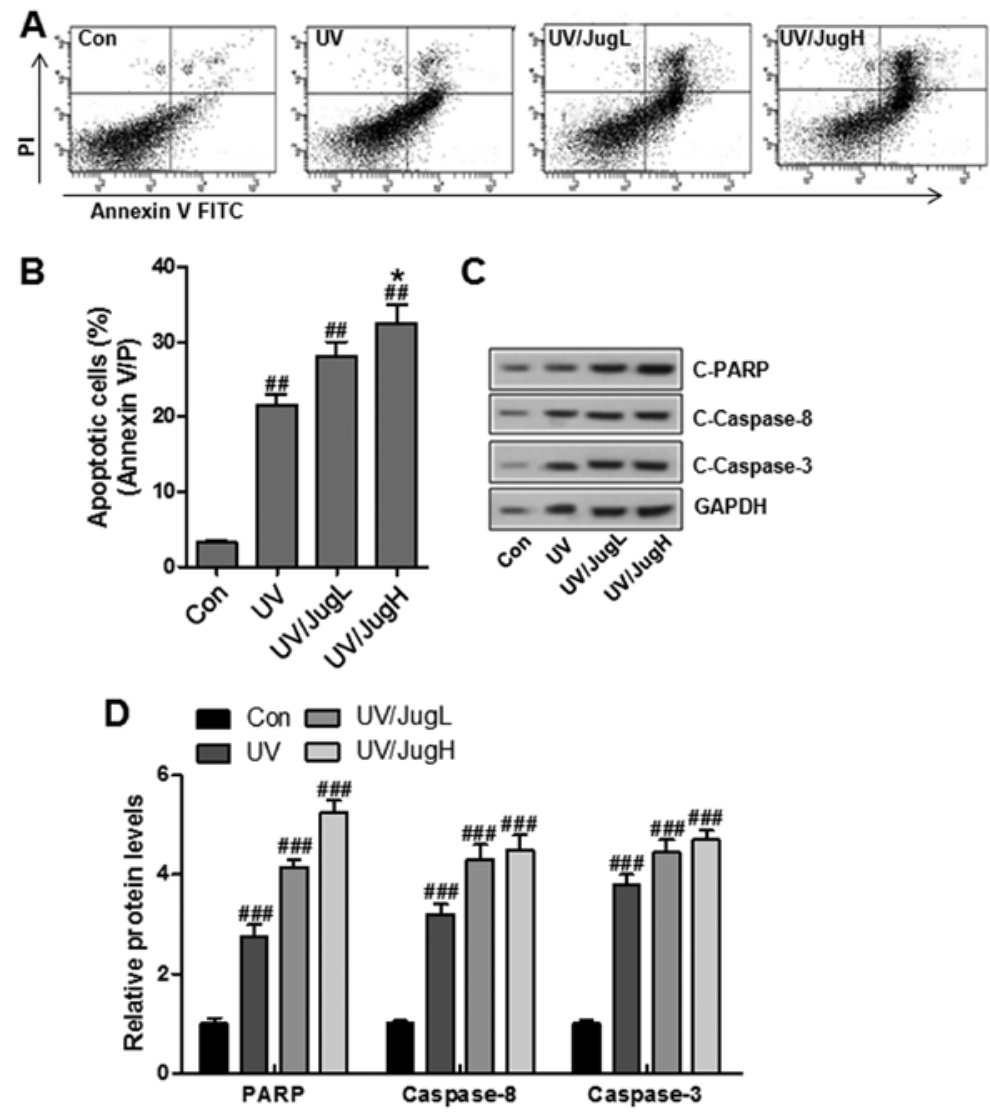

Figure 7. Combined UVB and juglanin treatment enhances apoptotic cell death, and induces caspase activation and PARP-1 cleavage. (A and B) Annexin V/PI assay followed by flow cytometric analysis of apoptosis in B16F10 cells $24 \mathrm{~h}$ post-UVB/juglanin treatment. (C) Western blot analysis of C-caspase-3, C-caspase- 8 activation and C-PARP in B16F10 cells $24 \mathrm{~h}$ post-UVB/juglanin treatment. (D) C-caspase-3, C-caspase-8 and PARP protein expression levels were semi-quantified and normalized to GAPDH. Data are presented as the means \pm standard deviation of three independent experiments. ${ }^{\# \#} \mathrm{P}<0.001$ compared with the Con group. FITC, fluorescein isothiocyanate; JugH, high juglanin; JugL, low juglanin; PARP, poly (ADP-ribose) polymerase; PI, propidium iodide; UVB, ultraviolet B.

A
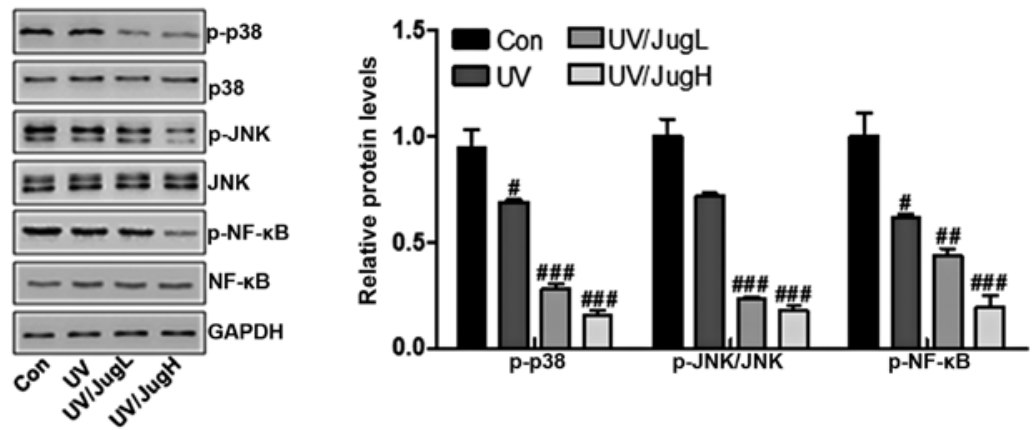

B
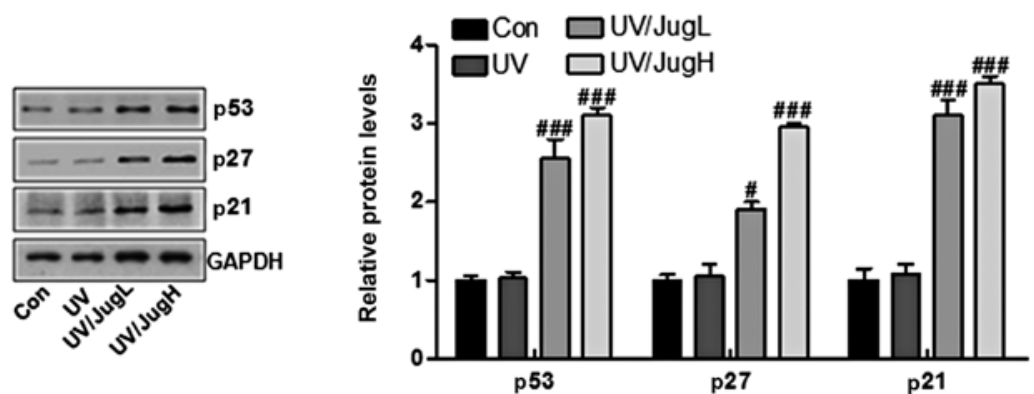

Figure 8. Effects of juglanin on major protein regulators of $\mathrm{p} 38 / \mathrm{JNK}$ and cell proliferation-associated signals in UVB irradiated B16F10 cells. (A) Western blotting of p-p38, p-JNK and p-NF- KB in B16F10 cells $24 \mathrm{~h}$ post-UVB/juglanin treatment. (B) Western blotting of p53, p27 and p21 activation in $\mathrm{B} 16 \mathrm{~F} 10$ cells $24 \mathrm{~h}$ post-UVB/juglanin treatment. Data are presented as the means \pm standard deviation of three independent experiments. ${ }^{\#} \mathrm{P}<0.05,{ }^{\# \#} \mathrm{P}<0.01$ and ${ }^{\# \#} \mathrm{P}<0.001$ compared with the Con group. Con, control; JNK, c-Jun N-terminal kinase; JugH, high juglanin; JugL, low juglanin; NF- $\mathrm{kB}$, nuclear factor-kB; p-, phosphorylated; UVB, ultraviolet B 
determine if the reduction in cell viability was caused by apoptosis, Annexin V/PI double staining was used to detect apoptosis in control and treated cells. Consistent with the previous results, juglanin led to a substantial increase in UVB-induced apoptosis (Fig. 7A and B). In addition, western blotting suggested that UVB and juglanin cotreatment promoted caspase activation and PARP cleavage, which are hallmark features of apoptosis (Fig. 7C and D).

Effects of juglanin on major protein regulators of p38/JNK and cell proliferation-associated signals in UVB-irradiated B16F10 cells. The MAPK pathway, which is activated in virtually all melanomas, regulates cell metastasis, proliferation and survival (13). The present study explored the effects of juglanin on p38 and JNK in UVB-irradiated B16F10 cells via western blotting. UVB irradiation of B16F10 cells downregulated the protein expression levels of p-p38 and p-JNK. Administration of UVB-irradiated B16F10 cells with juglanin induced further inactivation of p-p38 and p-JNK (Fig. 8A). Furthermore, $\mathrm{p}-\mathrm{NF}-\kappa \mathrm{B}$ was downregulated in cells expose to UV and treated with juglanin (Fig. 8A). Finally, p53, p27 and p21 were assessed to explore the role of juglanin in human skin cancer cells in vitro. The results indicated that p53,p27 and p21 were lowly expressed in the control group, and were stimulated by UV exposure when combined with juglanin, in a dose-dependent manner (Fig. 8B). These data further indicated that juglanin may perform its role in skin cancer suppression via cell proliferation inhibition in vitro.

\section{Discussion}

Skin cancer is one of the most common cancers worldwide, particularly in USA, which accounts for $\sim 50 \%$ of all human cancers (30). Solar UVB radiation is an ubiquitous environmental carcinogen, which leads to various cutaneous disorders, including melanoma and NMSCs (31). Previous studies have indicated that plant-derived compounds possess potential antimutagenic, anti-inflammatory and anticarcinogenic properties, and are gaining considerable attention regarding the prevention and inhibition of UVB-induced skin damage (32). Juglanin is a natural compound extracted from crude Polygonum aviculare, which exhibits inhibitory activity against inflammation and cancer growth (7). In the present study, juglanin was topically applied to UVB-exposed SKH-1 hairless mice by gavage in order to explore its effects on inflammatory markers, and the p38/JNK and PI3K/AKT-associated apoptosis signaling pathways (33). In response to UVB irradiation, activation of p38 MAPK and JNK is considered to induce apoptosis (34). Therefore, the inactivation of p38 and JNK is likely to enhance the therapeutic efficacy of juglanin in UVB-irradiated mice and cells. In our study, we found that in vivo p38 MAPK and JNK MAPK pathway was inactivated by juglanin in UVB-treated animals, while apoptosis was induced by juglanin. Herein, we supposed that there might be other signals involved in juglanin-regulated apoptosis in the skin of mice with UVB irradiation. Furthermore, in vivo, UV reduced caspase activation and PARP cleavage, whereas in vitro, it increased them. As for this, we hypothesized that there were different types of cells in tissue composition, while in vitro, only skin cancer cells were included (35). Consequently, different results were observed. Thus, further study is still required in future to comprehensively reveal the underlying molecular mechanism by which juglanin modulates apoptotic response in multiple types of cells.

Increasing evidence has indicated that exposure of the skin to UVB leads to the induction of inflammatory cytokine expression and production (36). The inflammatory response promotes skin cancer progression. In addition, TNF- $\alpha$, IL-1 $\beta$ and IL-18 serve a critical role in induction of UVB-induced skin hyperplasia and inflammation (37). In the present study, the expression levels of TNF- $\alpha$, IL- $1 \beta$ and IL-1 8 were increased following UVB exposure, whereas juglanin treatment significantly inhibited TNF- $\alpha$, IL-1 $\beta$ and IL-18 expression in the skin of UVB-exposed mice. Increased expression of proinflammatory cytokines further promotes infiltration of inflammatory cells (38). In addition, the $\mathrm{NF}-\kappa \mathrm{B}$ signaling pathway is associated with the transcription of numerous proinflammatory genes, including IL-1 $\beta$, IL-18 and TNF- $\alpha$ (39). It has previously been suggested that UVB radiation enhances NF- $\mathrm{B}$ signaling in mouse skin (40). PI3K/AKT has been suggested to have an important role in modulating the inflammatory response via regulation of $\mathrm{NF}-\kappa \mathrm{B}(41)$. A previous study reported that the PI3K/AKT-regulated $N F-\kappa B$ pathway was involved in myocardial injury following chronic stress (42). In addition, UVB radiation has been reported to stimulate numerous signal transduction pathways, including the PI3K/AKT pathway in vivo and in vitro (43). Given the possible causal relationship of inflammation with cancer, the present study hypothesized that the PI3K/AKT-regulated NF- $\mathrm{B}$ pathway may be involved in UVB-induced skin cancer. The in vivo results of the present study indicated that the NF- $\kappa \mathrm{B}$ signaling pathway was activated, accompanied with increased PI3K/AKT phosphorylation, in UVB-exposed mice. Notably, juglanin was able to suppress inflammation via NF- $\kappa \mathrm{B}$ inactivation and $\mathrm{AKT}$ inhibition.

DNA injury caused by UVB radiation results in stabilization and accumulation of p53 protein via transcriptional activation, which serves an essential role in cell cycle arrest. Once activated, the p53 protein translocates to the nucleus and activates numerous DNA-binding proteins and downstream effectors associated with cell cycle arrest and apoptotic induction (44). In UVB-exposed skin, p53 activation leads to p27 and p21 activation, which in turn suppresses cyclin D/CDK1 kinases in skin cancer. Blockage of the cell cycle helps to repair damaged DNA via nucleotide excision repair mechanisms (45). In the present study, western blotting clearly demonstrated that p53,p27 and p21 expression was decreased in the skin of UVB-exposed mice and cells. Juglanin treatment further augmented protein expression of p53, p27 and p21 in UVB-exposed mice and cells in vivo and in vitro. PCNA enhances degradation of the replication initiation factor complex induced by DNA damage; upregulated PCNA expression in UVB-induced DNA-injured cells is a result of the combination of p53 and the PCNA promoter (46). In the present study, treatment with juglanin significantly suppressed the protein expression levels of PCNA in the skin of UVB-exposed mice. In addition, cyclin D1 is an important proliferative marker, which regulates cell proliferation (47). Overexpression of cyclin D1 is associated with the development and progression of numerous types of cancer, including UVB-induced skin carcinogenesis (48). In the present study, UVB exposure significantly upregulated cyclin D1 expression. However, juglanin treatment significantly inhibited the expression of cyclin D1 in the skin of UVB-exposed mice. 
In conclusion, the present study indicated that juglanin treatment of SKH-1 mice following UVB exposure may lead to a significant decrease in the expression of inflammatory mediators, inflammatory cytokines, including TNF- $\alpha$, IL- $1 \beta$ and IL-18, and cell proliferative markers. In addition, juglanin suppressed the $\mathrm{p} 38 / \mathrm{JNK}$ and $\mathrm{PI} 3 \mathrm{~K} / \mathrm{AKT} / \mathrm{NF}-\kappa \mathrm{B}$ signaling pathways, which are involved in UVB-induced inflammation, cell survival, apoptosis and proliferation. Juglanin treatment also enhanced UVB-mediated p53, p27 and p21 protein expression. Notably, juglanin treatment is not toxic to mouse skin. Overall, these results indicated that juglanin may be developed as a natural and novel chemopreventive agent for the therapeutic treatment of UVB-induced skin cancer.

\section{Competing interests}

Authors declare that they have no competing interests.

\section{References}

1. D'Orazio J, Jarrett S, Amaro-Ortiz A and Scott T: UV radiation and the skin. Int J Mol Sci 14: 12222-12248, 2013

2. Chen ST, Geller AC and Tsao H: Update on the epidemiology of melanoma. Curr Dermatol Rep 2: 24-34, 2013.

3. Saladi RN and Persaud AN: The causes of skin cancer: a comprehensive review. Drugs Today (Barc) 41: 37-53, 2005.

4. Balk SJ; Section on Dermatology; Council on Environmental Health: Ultraviolet radiation: a hazard to children and adolescents. Pediatrics 127: 588-597, 2011.

5. Zhou GY, Yi YX, Jin LX, Lin W, Fang PP, Lin XZ, Zheng Y and Pan CW: The protective effect of juglanin on fructose-induced hepatitis by inhibiting inflammation and apoptosis through TLR4 and JAK2/STAT3 signaling pathways in fructose-fed rats. Biomed Pharmacother 81: 318-328, 2016.

6. Yang HH, Hwangbo K, Zheng MS, Son JK, Kim HY, Baek SH, Choi HC, Park SY and Kim JR: Inhibitory effects of juglanin on cellular senescence in human dermal fibroblasts. J Nat Med 68 : 473-480, 2014.

7. Phan VK, Nguyen TM, Minh CV, Nguyen HK, Nguyen HD, Nguyen PT, Nguyen $X C$, Nguyen $H N$, Nguyen $X N$, Heyden YV, et al: Two new C-glucosyl benzoic acids and flavonoids from Mallotus nanus and their antioxidant activity. Arch Pharm Res 33: 203-208, 2010.

8. Yang H, Sung SH, Kim J and Kim YC: Neuroprotective diarylheptanoids from the leaves and twigs of juglans sinensis against glutamate-induced toxicity in HT22 cells. Planta Med 77: 841-845, 2011.

9. KimHH,Oh MH,ParkKJ,HeoJH and Lee MW: Anti-inflammatory activity of sulfate-containing phenolic compounds isolated from the leaves of Myrica rubra. Fitoterapia 92: 188-193, 2014

10. Nguelefack TB, Mbakam FH, Tapondjou LA, Watcho P, Nguelefack-Mbuyo EP, Ponou BK, Kamanyi A and Park HJ: A dimeric triterpenoid glycoside and flavonoid glycosides with free radical-scavenging activity isolated from Rubus rigidus var. camerunensis. Arch Pharm Res 34: 543-550, 2011.

11. Schwarz S, Sauter D, Wang K, Zhang R, Sun B, Karioti A, Bilia AR, Efferth T and Schwarz W: Kaempferol derivatives as antiviral drugs against the 3 a channel protein of coronavirus. Planta Med 80: 177-182, 2014.

12. Asgari M, White E and Chren MM: Nonsteroidal anti-inflammatory drug use in the prevention and treatment of squamous cell carcinoma. Dermatol Surg 30: 1335-1342, 2004.

13. Khan N, Syed DN, Pal HC, Mukhtar H and Afaq F: Pomegranate fruit extract inhibits UVB-induced inflammation and proliferation by modulating NF- $\mathrm{KB}$ and MAPK signaling pathways in mouse skin. Photochem Photobiol 88: 1126-1134, 2012.

14. Thompson EJ, MacGowan J, Young MR, Colburn N and Bowden GT: A dominant negative c-jun specifically blocks okadaic acid-induced skin tumor promotion. Cancer Res 62 : 3044-3047, 2002.

15. Pal HC, Sharma S, Elmets CA, Athar M and Afaq F: Fisetin inhibits growth, induces $\mathrm{G}_{2} / \mathrm{M}$ arrest and apoptosis of human epidermoid carcinoma A431 cells: role of mitochondrial membrane potential disruption and consequent caspases activation. Exp Dermatol 22: 470-4752, 2013.
16. Meek DW: Tumour suppression by p53: a role for the DNA damage response? Nat Rev Cancer 9: 714-723, 2009.

17. Zhang Q, Bian H,LiY,GuoL, Tang Y andZhuH: Preconditioning with the traditional Chinese medicine Huang-Lian-Jie-Du-Tang initiates HIF-1 $\alpha$-dependent neuroprotection against cerebral ischemia in rats. J Ethnopharmacol 154: 443-452, 2014.

18. Livak KJ and Schmittgen TD: Analysis of relative gene expression data using real-time quantitative PCR and the 2(-Delta Delta C(T)) Method. Methods 25: 402-408, 2001.

19. Pal HC, Athar M, Elmets CA and Afaq F: Fisetin inhibits UVB-induced cutaneous inflammation and activation of $\mathrm{PI} 3 \mathrm{~K} / \mathrm{AKT} / \mathrm{NF} \kappa \mathrm{B}$ signaling pathways in SKH-1 hairless mice. Photochem Photobiol 91: 225-234, 2015.

20. Afaq F, Adhami VM and Mukhtar H: Photochemoprevention of ultraviolet B signaling and photocarcinogenesis. Mutat Res 571: 153-173, 2005.

21. Bowden GT: Prevention of non-melanoma skin cancer by targeting ultraviolet-B-light signalling. Nat Rev Cancer 4: 23-35, 2004.

22. Segrelles C, Lu J, Hammann B, Santos M, Moral M, Cascallana JL, Lara MF, Rho O, Carbajal S, Traag J, et al: Deregulated activity of Akt in epithelial basal cells induces spontaneous tumors and heightened sensitivity to skin carcinogenesis. Cancer Res 67: 10879-10888, 2007.

23. Neagu M, Constantin C, Dumitrascu GR, Lupu AR, Caruntu C, Boda D and Zurac S: Inflammation markers in cutaneous melanoma - edgy biomarkers for prognosis. Discoveries 3: e38, 2015

24. Fujiki H, Sueoka E and Suganuma M: Tumor promoters: from chemicals to inflammatory proteins. J Cancer Res Clin Oncol 139: 1603-1614, 2013.

25. Yan C, Grimm WA, Garner WL, Qin L, Travis T, Tan N and Han YP: Epithelial to mesenchymal transition in human skin wound healing is induced by tumor necrosis factor-alpha through bone morphogenic protein-2. Am J Pathol 176: 2247-2258, 2010.

26. Rogers HW, Weinstock MA, Harris AR, Hinckley MR, Feldman SR, Fleischer AB and Coldiron BM: Incidence estimate of nonmelanoma skin cancer in the United States, 2006. Arch Dermatol 146: 283-287, 2010.

27. Tak PP and Firestein GS: NF-kappaB: a key role in inflammatory diseases. J Clin Invest 107: 7-11, 2001.

28. Li J, Cheng Y, Qu W, Sun Y, Wang Z, Wang H and Tian B: Fisetin, a dietary flavonoid, induces cell cycle arrest and apoptosis through activation of p53 and inhibition of NF-kappa B pathways in bladder cancer cells. Basic Clin Pharmacol Toxicol 108: 84-93, 2011.

29. Kassi E, Sourlingas TG, Spiliotaki M, Papoutsi Z, Pratsinis H, Aligiannis $\mathrm{N}$ and Moutsatsou P: Ursolic acid triggers apoptosis and Bcl-2 downregulation in MCF-7 breast cancer cells. Cancer Invest 27: 723-733, 2009.

30. Kornek T and Augustin M: Skin cancer prevention. J Dtsch Dermatol Ges 11: 283-296, 2013.

31. Nijsten T, Colpaert CG, Vermeulen PB, Harris AL, Van Marck E and Lambert J: Cyclooxygenase-2 expression and angiogenesis in squamous cell carcinoma of the skin and its precursors: a paired immunohistochemical study of 35 cases. Br J Dermatol 151: 837-845, 2004.

32. Kim RH and Armstrong AW: Nonmelanoma skin cancer. Dermatol Clin 30: 125-139, 2012.

33. Li B, Zhang G, Li R and Duan C: Phosphoinositide 3-kinase/Akt Pathway Mediates Fip1-like1-platelet-derived Growth Factor Receptor $\alpha$-induced Cell Infiltration and Activation: Possible Molecular Mechanism for the Malignant Phenotype of Chronic Eosinophilic Leukemia. Cancer Transl Med 1:31-34, 2015.

34. George J, Singh M, Srivastava AK, Bhui K, Roy P, Chaturvedi PK and Shukla Y: Resveratrol and black tea polyphenol combination synergistically suppress mouse skin tumors growth by inhibition of activated MAPKs and p53. PLoS One 6: e23395, 2011.

35. Larisch P, Verwanger T, Linecker $M$ and Krammer B: The interrelation between a pro-inflammatory milieu and fluorescence diagnosis or photodynamic therapy of human skin cell lines. Photodiagnosis Photodyn Ther 11: 91-103, 2014.

36. Joosse A, Koomen ER, Casparie MK, Herings RM, Guchelaar HJ and Nijsten T: Non-steroidal anti-inflammatory drugs and melanoma risk: large Dutch population-based case-control study. J Invest Dermatol 129: 2620-2627, 2009.

37. Johannesdottir SA, Chang ET, Mehnert F, Schmidt M, Olesen AB and Sørensen HT: Nonsteroidal anti-inflammatory drugs and the risk of skin cancer: a population-based case-control study. Cancer 118: 4768-4776, 2012 . 
38. Nedoszytko B, Sokołowska-Wojdyło M, RuckemannDziurdzińska K, Roszkiewicz J and Nowicki RJ: Chemokines and cytokines network in the pathogenesis of the inflammatory skin diseases: atopic dermatitis, psoriasis and skin mastocytosis. Postepy Dermatol Alergol 31: 84-91, 2014.

39. Shen J, Abel EL, Riggs PK, Repass J, Hensley SC, Schroeder LJ Temple A, Chau A, McClellan SA, Rho O, et al: Proteomic and pathway analyses reveal a network of inflammatory genes associated with differences in skin tumor promotion susceptibility in DBA/2 and C57BL/6 mice. Carcinogenesis 33: 2208-2219, 2012.

40. Suganuma M, Okabe S, Kurusu M, Iida N, Ohshima S, Saeki Y, Kishimoto T and Fujiki H: Discrete roles of cytokines, TNF- $\alpha$, IL-1, IL-6 in tumor promotion and cell transformation. Int J Oncol 20: 131-136, 2002.

41. Yang C, Zhao T, Lin M, Zhao Z, Hu L, Jia Y, Xue Y, Xu M, Tang Q, Yang B, et al: Helix B surface peptide administered after insult of ischemia reperfusion improved renal function, structure and apoptosis through beta common receptor/erythropoietin receptor and PI3K/Akt pathway in a murine model. Exp Biol Med (Maywood) 238: 111-119, 2013.

42. Moore T, Beltran L, Carbajal S, Strom S, Traag J, Hursting SD and DiGiovanni J: Dietary energy balance modulates signaling through the Akt/mammalian target of rapamycin pathways in multiple epithelial tissues. Cancer Prev Res (Phila) 1: 65-76, 2008.

43. Wilker E, Lu J, Rho O, Carbajal S, Beltrán L and DiGiovanni J: Role of PI3K/Akt signaling in insulin-like growth factor-1 (IGF-1) skin tumor promotion. Mol Carcinog 44: 137-145, 2005.
44. Kleiner HE, Vulimiri SV, Starost MF, Reed MJ and DiGiovanni J: Oral administration of the citrus coumarin, isopimpinellin, blocks DNA adduct formation and skin tumor initiation by 7,12-dimethylbenz $[a]$ anthracene in SENCAR mice. Carcinogenesis 23: 1667-1675, 2002.

45. Chen T: The role of microRNA in chemical carcinogenesis. J Environ Sci Health C Environ Carcinog Ecotoxicol Rev 28: 89-124, 2010

46. Li J, Qu W, Cheng Y, Sun Y, Jiang Y, Zou T, Wang Z, Xu Y and Zhao H: The inhibitory effect of intravesical fisetin against bladder cancer by induction of p53 and down-regulation of NF-kappa $\mathrm{B}$ pathways in a rat bladder carcinogenesis model. Basic Clin Pharmacol Toxicol 115: 321-329, 2014.

47. Wong YK, Lin SC, Chang CS, Tseng YH, Liu CJ, Lin HC and Chang KW: Cyclin D1 genotype in areca-associated oral squamous cell carcinoma. J Oral Pathol Med 32: 265-270, 2003.

48. Yaylim-Eraltan I, Arikan S, Yildiz Y, Cacina C, Ergen HA, Tuna G, Görmüs U, Zeybek U and Isbir T: The influence of cyclin D1 A870G polymorphism on colorectal cancer risk and prognosis in a Turkish population. Anticancer Res 30: 2875-2880, 2010.

This work is licensed under a Creative Commons Attribution-NonCommercial-NoDerivatives 4.0 International (CC BY-NC-ND 4.0) License. 